\section{Effects of Different Rotary Files Combined with Different Irrigation Needles on Apically Extruded Debris}

\author{
Emel Uzunoglu' ${ }^{1}$ Sevinc Aktemur Turker ${ }^{2}$, Melahat Görduysus ${ }^{1}$
}

\author{
'Department of Endodontics, \\ Faculty of Dentistry, Hacettepe \\ University, Ankara, Turkey \\ ${ }^{2}$ Department of Endodontics, \\ Faculty of Dentistry, Bülent Ecevit \\ University, Zonguldak, Turkey \\ Correspondence: Emel Uzunoglu, \\ Department of Endodontics, \\ Faculty of Dentistry, Hacettepe \\ University, Sihhiye, Ankara, Turkey, \\ 06100. Tel: +90-312-305-2260. \\ e-mail: emel_dt@hotmail.com
}

\begin{abstract}
The aim of this study was to compare the apically extruded debris associated with ProTaper Next and OneShape Apical files using two different irrigation needles, open-ended and closed-ended (Max-I-Probe). Forty-eight mandibular premolars were assigned to four groups $(n=12)$ as follows: Group PTN-SN: Root canal was prepared with ProTaper Next (PTN) and irrigated with open-ended standard needle; Group PTN-MP: Root canal was prepared with PTN and irrigated with Max-I-Probe; Group OSA-SN: Root canal was prepared with OneShape Apical (OSA) and irrigated with open-ended needle; Group OSA-MP: Root canal was prepared with OSA and irrigated with Max-I-Probe. Debris extruded during instrumentation was collected into pre-weighed Eppendorf tubes. After storage in an incubator at $70^{\circ} \mathrm{C}$ for 5 days, the Eppendorf tubes were weighed to obtain the final weight with extruded debris. The difference between pre-and post-debris weights was calculated and statistical analysis was performed using Kruskal-Wallis and Mann-Whitney U tests $(p<0.05)$. No statistically significant difference was observed between files and needles regarding amount of apically extruded debris ( $p>0.05)$. OneShape Apical and ProTaper Next resulted in extrusion of debris beyond the apical foramen, regardless of needle tip.
\end{abstract}

Key Words: needles, root canal irrigants, root canal preparation.

\section{Introduction}

Chemomechanical preparation of root canal is the most crucial step of root canal treatment. Irrigants, dentin chips, pulp tissue and microorganisms may be extruded into the periradicular tissues during this step, and these extruded materials may cause postoperative pain and complications $(1,2)$. Previous studies have reported that all preparation techniques and instruments are associated with some debris extrusion apically (3-9).

Manufacturers have designed new nickel titanium rotary files that prepare root canal faster, easier and at the same time, preserve the original canal shape with considerably less iatrogenic errors $(10,11)$. ProTaper Next (PTN) is a new set of rotary instruments designed with progressive and regressive percentage tapers. It has a snakelike swaggering movement because of an off-centered rectangular cross section that generates an enlarged space for debris removal according to manufacturer. These instruments are manufactured from M-wire NiTi alloy that is claimed to improve file flexibility and resist cyclic fatigue while retaining cutting efficiency (12). Recently manufactured OneShape Apical (OSA) files are single-use NiTi finishing instruments, which are used after shaping with OneShape in order to prepare the apical part of the root canal. Two instruments are available: OSA 1 (\#30/.06) and OSA 2 (\#37/.06). OSA 1 instruments have a constant
0.06 taper only between D0-D5. Between D6-D16 it has zero taper. It is made of a conventional austenite 55-NiTi alloy. The cross-section represents three cutting edges in the tip region and two cutting edges in the middle. Design of file changes progressively and the S-shaped cross section shows two cutting edges at the shank. This design is purported to eliminate threading and binding of the instrument during continuous rotation (13).

Apart from files there are several factors such as anatomy of the apical area, type and size of the irrigation needle, needle placement depth, amount and flow rate of the irrigant that affect the amount of apically extruded debris (14-18).

The aim of this study was to compare the amount of apically extruded debris with ProTaper Next and OneShape systems with two different needle tips. There is no current study evaluating the amount of apically extruded debris with OneShape Apical. There is several studies reported apical extrusion with PTN, without combining with different needle types $(4-6,8,9)$. The null hypothesis was that there are no differences in the amount of apically extruded debris between: (i) file systems and (ii) needle designs.

\section{Material and Methods}

Forty-eight extracted mandibular premolars with fully formed apices, curvature between 0 and $15^{\circ}$ according to 
the Schneider method (19), and free of root resorption, previous root fillings, caries/cracks/fractures on the root surface were selected. The presence of a single canal was confirmed with radiographs taken in buccal and proximal directions. The teeth were cleaned of debris and soft tissue remnants and stored in distilled water until use. The length of the teeth was standardized to $21 \mathrm{~mm}$ by flattening the top of buccal cusps with silicon carbide discs. Then, an access cavity was prepared in each tooth. Working length was determined by advancing a size $10 \mathrm{~K}$-file (Mani Inc., Tochigi, Japan) into the canal until it was just visible at the foramen and then subtracting $1 \mathrm{~mm}$ from this measurement. The size of the minor constriction was controlled by advancing a size $15 \mathrm{~K}$-file (Mani Inc.) to the working length. Teeth where the tip of the file extruded beyond the apical foramen were excluded $(3,4)$.

A similar experimental model described previously was used for determining extruded debris $(3-9,20)$. Stoppers were separated from the Eppendorf tubes. An analytical balance (Radwag, Radom, Poland) with an accuracy of $10^{-4} \mathrm{~g}$ was used to measure the initial weights of the tubes. Three consecutive weights were obtained for each tube, and the mean value was calculated. A hole was created on each UT, USA) was placed alongside the stopper. This acted as a drainage cannula and helped to balance the air pressure inside and outside the tubes. Then, each stopper with the tooth and the needle was attached to its Eppendorf tube, and the tubes were fitted into vials with cyanoacrylate. A rubber-dam sheet was used to prevent leakage of overflowing irrigant and also the root apex shielded from operator during the instrumentation procedure. Teeth were divided into four groups $(n=12)$ as follows:

Group PTN-SN: PTN (Dentsply Maillefer, Ballaigues, Switzerland) files were used with the sequence ProTaper Universal SX, PTN X1 (\#17/04), X2 (\#25/06), X3 (\#30/.07), at a rotational speed of $300 \mathrm{rpm}$ and $200 \mathrm{gcm}$ torque with a torque- controlled endodontic motor (X-Smart; Dentsply Maillefer). Each file was used with a brushing motion. All instruments were used at WL. Irrigation with distilled water was performed with an open-ended standard needle (SN; 27 gauge; Hayat, Istanbul, Turkey).

Group PTN-MP: The instrumentation procedure was similar to that in Group PTN-SN. However, the irrigation procedure was performed with Max-I-Probe side-vented closed ended needle (MP; 28 gauge, Dentsply Rinn, Elgin, IL, USA).

Group OSA-SN: The OS files (Micro-Mega, Besançon, France) were used with the sequence OS (\#25/.06) and OSA 1(\#30/.06) at a rotational speed of $400 \mathrm{rpm}$ and 400 $\mathrm{gcm}$ torque with a torque- controlled endodontic motor
(X-Smart; Dentsply Maillefer). When apical resistance was encountered, the instrument was removed and cleaned, and the root canal was irrigated with distilled water. Irrigation was performed with an open-ended standard needle (SN; 27 gauge; Hayat).

Group OSA-MP: The instrumentation procedure was similar to that of Group OSA-SN. However, the irrigation procedure was performed with Max-I-Probe side-vented closed ended needle (MP; 28 gauge, Dentsply Rinn).

One operator conducted canal preparation and irrigation during the experiment. Irrigation was performed after each file, using $2 \mathrm{~mL}$ and $4 \mathrm{~mL}$ distilled water for PTN and $\mathrm{OS}$ groups, respectively. The total volume of irrigant in each group was the same and $8 \mathrm{~mL}$ for every tooth. The needle was inserted into the canal within $3 \mathrm{~mm}$ from the working length without binding and moved in an up-anddown motion dynamically during irrigation (15). Irrigation was performed with minimum pressure.

On completion of the preparation, the canals were irrigated with $2 \mathrm{~mL}$ of distilled water as a final irrigation, dried with paper points (Diadent Cheongju-si, Chungcheongbuk-do, Korea), and the teeth were removed from the Eppendorf tubes. The apical part of the tooth was washed with distilled water in order to collect the apically extruded debris that had adhered to the root. All of the tubes were incubated at $70{ }^{\circ} \mathrm{C}$ for 5 days before being weighed again, to evaporate the irrigant in the Eppendorf tubes. After the incubation period, the tubes were weighed again 3 times. The average of these measurements was considered to be the weight of the tube plus the debris.

The difference between pre- and post-weights was calculated, and statistical evaluation was performed using SPSS 19.0 software (SPSS Inc., Chicago, IL, USA). Normality distribution of data was determined by Shapiro-Wilk test. Continuous variables were expressed as median (minimummaximum). Apical extrusion was compared with the Kruskal-Wallis and Mann-Whitney U test $(p<0.05)$.

\section{Results}

The mean weight standard deviation and median for each group are presented in Table 1. The results indicated that both files and needles caused measurable apical extrusion of debris. There were no significant differences among groups ( $p=0.283$ ); mean amount of apically extruded debris sequence was OSA-SN $\geq P T N-S N \geq P T N-M P \geq O S A-M P$. No statistically significant difference was observed between files regardless of needle tips $(p=0.321)$ and also needles tips, regardless of files ( $p=0.183)$.

\section{Discussion}

The results of the present study showed that both file systems and needle types tested produced apically extruded 
debris in vitro. It has been reported that file system, needle type, needle insertion depth and apical preparation size had a significant effect on irrigant extrusion $(4,9,17)$. Single-rooted mandibular premolar teeth were used and special care was taken to attain groups that were as similar as possible in terms of anatomical feature. Only teeth with compatible foramen to size $15 \mathrm{~K}$-files were selected. The apical diameter of master apical instruments in all the groups were standardized at ISO size 30 to avoid any variations in the amount of extruded debris due to the size of apical enlargement.

Apical preparation size and needle insertion depth were constant in the present study. Closed-ended side-vented needle Max-I-Probe was compared to standard openended needle. It was reported that the open-ended needle extruded significantly more irrigant than the closed-ended (17). Although the standard needle exhibited a higher numeric amount of debris $(0.00028 \mathrm{~g})$ than the Max-IProbe $(0.00020 \mathrm{~g})$, the differences between groups were not statistically different. It is reported also both side-venting and standard needles can be used for irrigation safely and effectively if a dynamic irrigation technique (moving the needle up and down inside the canals while irrigating) is employed without binding of the needle in the canal (15). The needle was inserted into the canal within $3 \mathrm{~mm}$ from the working length without binding and moved dynamically during irrigation procedure. The tip of the irrigating needle should be positioned as apically as possible in the root canal for efficient root canal according to Sedgley et al. (21). On the other hand, if the tip of the needle is positioned too close to the apical foramen, the risk of extrusion of irrigant into the periapical tissues increases (17). Extrusion of toxic irrigants can be resulted in considerable pain and inflammation (22).

The new swaggering motion of the ProTaper Next system serves to minimize the engagement between dentin and the file and enhances pushing debris out of the canal (23). There are limited previous studies that evaluated the apically extruded debris with ProTaper Next files $(4-6,8,9)$, with side-vented open-ended needles $(4,8)$. In most of the studies, preparation was done up to X2 $(4,5,9)$. Ozsu et al. (8) prepared teeth up to $\mathrm{X} 4$ and irrigated with 31 gauge double side-port needle, while Koçak et al. (6) prepared teeth up to $\mathrm{X} 3$, but there was no information regarding needle type in latter one. In the present study, the weights of apically extruded debris of teeth prepared up to X3 and irrigated with two different needles were nearly similar and took place in the previously reported weight's range $(4-6,8,9)$.

OneShape is characterized by a changing triangular cross-section and it was reported that OneShape (25/.06) maintained the original canal curvature well and was safe to use in severely curved root canals (10). Bürklein et al. (3) and Küçükyılmaz et al. (7) evaluated apically extruded debris with OneShape as a single-file system. To the best of our knowledge, there are no data in the literature on the extrusion of apical debris with the OneShape Apical files. Bürklein et al. (3) reported the weight of apically extruded debris with OneShape combined with 31 gauge double sideport needle as $0.00019 \pm 0.00009 \mathrm{~g}$, while Küçükyılmaz et al. (7) reported the weight of apically extruded debris with OneShape combined with 25 gauge needle as $0.000431 \pm$ $0.000171 \mathrm{~g}$. In the current study when OneShape Apical combined with standard open-ended needle apically extruded debris was $0.00031 \pm 0.00021 \mathrm{~g}$, however when irrigation was done with Max-I-Probe needle, weight of apically extruded debris was less as $0.00018 \pm 0.00012 \mathrm{~g}$.

Distilled water was used as an irrigation solution to avoid any possible crystallization of sodium hypochlorite that could alter the weight of dentin debris and compromise the reliability of the results (24). It is important to emphasize that file systems were compared in an experimental model using that collected apically extruded debris from extracted teeth. This methodology is generally accepted and has been used previously $(3-9,20)$. Although the technique allows a comparison of the file systems under identical conditions, it does have limitations (24). The main disadvantage of the method is that vital periapical tissues cannot be mimicked. Apical extrusion was not limited, because of the absence of a physical backpressure provided by periapical tissues in vivo (25). This is an imminent shortcoming of in vitro designs with no periapical resistance; as a result certain degree of caution should be taken when transferring the present results to the clinical situation. If the quantities of debris extruded in this study were extruded routinely in clinical practice, a higher incidence of postoperative pain might be anticipated. Furthermore, this study was limited to teeth with mature root morphology. The observed results should not be generalized to teeth with immature root development and open apices.
1. The number of specimens, mean extrusion values (g), standard deviations (SD), medi minimum and maximum values for each group. PTN: ProTaper Next, SN: open-ended standard needle, OSA: One Shape Apical, MP: Max-1-Probe

\begin{tabular}{lccccc}
\hline Group $(\mathrm{n}=12)$ & Mean & SD & Median & Minimum & Maximum \\
\hline PTN-SN & 0.00030 & 0.00019 & 0.00030 & 0.0001 & 0.0007 \\
PTN-MP & 0.00028 & 0.00018 & 0.00030 & 0.0001 & 0.0007 \\
OSA-SN & 0.00031 & 0.00021 & 0.00025 & 0.0001 & 0.0008 \\
OSA-MP & 0.00018 & 0.00012 & 0.00010 & 0.0001 & 0.0005 \\
\hline
\end{tabular}


Within the limitations of this in vitro study, ProTaper Next and OneShape Apical files extruded debris apically, regardless of needle type. Further research is needed for evaluating extrusion potential of OneShape Apical systems.

\section{Resumo}

0 objetivo do presente estudo foi comparar a extrusão apical de restos de preparação de canais, associada às brocas ProTaper Next e OneShape Apical usando duas agulhas de irrigação, de ponta aberta e ponta fechada (Max-I-Probe). Quarenta e oito premolares inferiores foram divididos em quatro grupos $(n=12)$ : Grupo PTN-SN: o canal radicular foi preparado com ProTaper Next (PTN) e irrigado com agulha convencional de ponta aberta; Grupo PTN-MP: o canal radicular foi preparado com PTN e irrigado com Max-I-Probe; Grupo OSA-SN: o canal radicular foi preparado com OneShape Apical (OSA) e irrigado com agulha de ponta aberta; Grupo OSA-MP: o canal radicular foi preparado com OSA e irrigado com MaxI-Probe. Os restos extrudados apicalmente foram coletados em tubos Eppendorf previamente pesados. Após armazenagem por cinco dias a 70 ${ }^{\circ} \mathrm{C}$, os tubos Eppendorf foram pesados para obter o peso final com os residuos. A diferença entre as pesagens antes e depois foi calculada e análise estatística foi feita usando os testes de Kruskal-Wallis e Mann-Whitney U $(p<0,05)$. Não houve diferença estatisticamente significante entre as brocas e agulhas com relação à quantidade de resíduos extrudados $(p>0,05)$. As brocas ProTaper Next e OneShape Apical promoveram extrusão além do forame apical, independente do tipo de agulha utilizada.

\section{References}

1. Reddy SA, Hicks ML. Apical extrusion of debris using two hand and two rotary instrumentation techniques. J Endod 1998;24:180-183.

2. Gondim E Jr, Setzer FC, Dos Carmo CB, Kim S. Postoperative pain after the application of two different irrigation devices in a prospective randomized clinical trial. J Endod 2010;36:1295-1301.

3. Bürklein S, Benten S, Schäfer E. Quantitative evaluation of apically extruded debris with different single-file systems: Reciproc, F360 and OneShape versus Mtwo. Int Endod J 2014;47:405-409.

4. Capar ID, Arslan H, Akcay M, Ertas H. An in vitro comparison of apically extruded debris and instrumentation times with ProTaper Universal, ProTaper Next, Twisted File Adaptive, and HyFlex instruments. J Endod 2014;40:1638-1641.

5. Kirchhoff AL, Fariniuk LF, Mello I. Apical extrusion of debris in flat-oval root canals after using different instrumentation systems. J Endod 2015;41:237-241.

6. Koçak MM, Ciçek E, Koçak S, Saglam BC, Yılmaz N. Apical extrusion of debris using ProTaper Universal and ProTaper Next rotary systems. Int Endod J 2015;48:283-286.

7. Küçükyilmaz E, Savas S, Saygili G, Uysal B. Assessment of apically extruded debris and irrigant produced by different nickel-titanium instrument systems. Braz Oral Res 2015;29:1-6.

8. Ozsu D, Karatas E, Arslan H, Topcu MC. Quantitative evaluation of apically extruded debris during root canal instrumentation with ProTaper Universal, ProTaper Next, WaveOne, and self-adjusting file systems. Eur J Dent 2014;8:504-508.
9. Ustün $Y$, Canakçi BC, Dinçer AN, Er O, Düzgün S. Evaluation of apically extruded debris associated with several $\mathrm{Ni}$-Ti systems. Int Endod J 2015;48:701-704.

10. Bürklein $\mathrm{S}$, Benten $\mathrm{S}$, Schäfer E. Shaping ability of different single-file systems in severely curved root canals of extracted teeth. Int Endod J 2013:46:590-597.

11. Capar ID, Ertas H, Ok E, Arslan H, Ertas ET. Comparative study of different novel nickel-titanium rotary systems for root canal preparation in severely curved root canals. J Endod 2014;40:852-856.

12. Alapati SB, Brantley WA, lijma M, Clark WA, Kovarik L, Buie C, et al. Metallurgical characterization of a new nickel-titanium wire for rotary endodontic instruments. J Endod 2009;35:1589-1593.

13. Bürklein S, Hiller C, Huda M, Schäfer E. Shaping ability and cleaning effectiveness of Mtwo versus coated and uncoated EasyShape instruments in severely curved root canals of extracted teeth. Int Endod J 2011;44:447-457.

14. Altundasar $E_{1}$ Nagas $E_{1}$ Uyanik O, Serper A. Debris and irrigant extrusion potential of 2 rotary systems and irrigation needles. Oral Surg Oral Med Oral Pathol Oral Radiol Endod 2011;112:e31-e35.

15. Devi AA, Abbott PV. Comparison of the flow characteristics of irrigants with standard and Max-i-Probe needles. Aust Endod J 2012;38:50-54.

16. Howard RK, Kirkpatrick TC, Rutledge RE, Yaccino JM. Comparison of debris removal with three different irrigation techniques. J Endod 2011;37:1301-1305.

17. Psimma Z, Boutsioukis C, Kastrinakis E, Vasiliadis L. Effect of needle insertion depth and root canal curvature on irrigant extrusion ex vivo. J Endod 2013;39:521-524.

18. Yeter KY, Evcil MS, Ayranci LB, Ersoy I. Weight of apically extruded debris following use of two canal instrumentation techniques and two designs of irrigation needles. Int Endod J 2013;46:795-799.

19. Schneider SW. A comparison of canal preparations in straight and curved root canals. Oral Surg Oral Med Oral Pathol 1971;32:271-275.

20. Myers GL, Montgomery S. A comparison of weights of debris extruded apically by conventional filing and Canal Master techniques. J Endod 1991;17:275-279.

21. Sedgley $C M$, Nagel AC, Hall D, Applegate B. Influence of irrigant needle depth in removing bioluminescent bacteria inoculated into instrumented root canals using real- time imaging in vitro. Int Endod J 2005;38:97-104.

22. Serper A, Ozbek M, Calt S. Accidental sodium hypochlorite-induced skin injury during endodontic treatment. J Endod 2004;30:180-181.

23. Ruddle CJ, Machtou P, West JD. The shaping movement: Fifthgeneration technology. Dent Today 2013;32:94,96-99.

24. Tanalp J, Güngör T. Apical extrusion of debris: a literature review of an inherent occurrence during root canal treatment. Int Endod J 2014;47:211-221.

25. Bonaccorso A, Cantatore G, Condorelli GG, Schäfer E, Tripi TR. Shaping ability of four nickel-titanium rotary instruments in simulated S-shaped canals. J Endod 2009;35:883-886.

Received February 17, 2015 Accepted June 24, 2015 